\title{
Duodenum and Ampulla of Vater Neuroendocrine Tumor pNO TNM Finding v8
}

National Cancer Institute

\section{Source}

National Cancer Institute. Duodenum and Ampulla of Vater Neuroendocrine Tumor pNO

TNM Finding v8. NCI Thesaurus. Code C135073.

Duodenum and ampulla of Vater neuroendocrine tumor without regional lymph node involvement. (from AJCC 8th Ed.) 